\title{
DANSKE RESUMEER
}

\section{Martin Lindhardt: Fænomenologien i antropologien}

Denne artikel redegør i store træk for fænomenologiens relevans og potentiale i antropologisk og kultursociologisk forskning. Der lægges ud med et teorihistorisk oprids, hvor centrale fænomenologiske tænkere (Husserl, Heidegger, Schutz og Merleau-Ponty) og begreber præsenteres. Efterfølgende diskuteres fænomenologiens rolle i og bidrag til antropologiske studier af forskellige temaer, nærmere betegnet sygdom, køn, menneskets forhold til naturen og globalisering, samt til de seneste årtiers erkendelsesteoretiske debatter. Afslutningsvis introduceres temanummerets resterende artikler.

Søgeord: Fænomenologi, antropologi, sociologi, krop, bevidsthed, erfaring, perception, epistemologi.

\section{Anne Line Dalsgård: Streger på nattehimlen}

Artiklen bygger på en undersøgelse af kvindelig sterilisation i Nordøstbrasilien, udført i årene 1997-2000. Studiet er publiceret i bogen Matters of Life and Longing (2004). I en refleksion over dette arbejde argumenterer jeg for, at skønlitterær tekst - inklusive forestillingerne om den Andens aldrig helt tilgængelige subjektivitet - kan udgøre et fænomenologisk studie i sig selv og indgå som eksperiment i den antropologiske analyse. Forsøget på at skrive den Andens subjektive verden frem lægger de formodede forbindelser blot, som binder antropologens observationer og fornemmelser af hende sammen. Uden en sådan blotlæggelse vil antropologen naivt kunne fortsætte sit arbejde, som havde intet spring udi gætværk fundet sted. Dette er imidlertid ikke muligt, når gætværket gøres så tydeligt, som det gøres i beskrivelsen af den Andens tanker og følelser. Skønt denne artikel fokuserer specifikt på den antropologiske brug af fænomenologisk analyse, mener jeg, at en naiv indstilling til den Anden er en potentiel risiko i enhver antropologisk analyse, som tager „det indfødte synspunkt“ som sit udgangspunkt. Samtidig må man spørge, hvad alternativet til dette udgangspunkt er. Risikerer vi ikke at forblive selvcentrerede og irrelevante, hvis vi ikke strækker os ud mod det fremmede? Min konklusion i denne artikel er i hvert fald (skønt anderledes udtrykt): Hellere springe ud i gætværket med åbne øjne end at forblive ligeglad med verden.

Søgeord: Subjektivitet, skønlitterær tekst, moderskab, motivation, fænomenologi, metode 


\section{Inge Kryger Pedersen: Lytninger i alternativ behandling. En fænomenologisk analyse}

I den evidensbaserede medicins æra prioriteres tekniske færdigheder, standardiseringer og behandlinger med videnskabeligt beviste virkninger i effektiviseringen af pleje og behandling. Ikke desto mindre er alternativ behandling, som hverken er reguleret, kontrolleret, standardiseret eller autoriseret og med yderst begrænset videnskabelig evidens, meget populær i Danmark og andre lande. I denne artikel, der bygger på etnografiske undersøgelser inden for tre af de mest populære former for alternativ behandling i Danmark, undersøges lytning som fænomen med henblik på at bidrage til forklaringerne og forståelsen af behandlingernes popularitet. Forskellige former for lytning som fænomenologiske og intersubjektive processer er i fokus: behandlernes lytning til deres klienter, klienternes lytning til deres behandlere og egen krop, forskerens lytning som en fænomenologisk analytisk praksis og undersøgelsesstrategi. Lytning er et overset område sammenlignet med blikket, for eksempel det medicinske eller kliniske blik i forskning inden for sundhedsområdet. I den eksisterende litteratur om lytning er der kun få undersøgelser af patienters eller brugeres oplevelser af lytning. Denne artikel anvender et lyttebegreb, der adskiller sig fra det at høre som en fysiologisk proces, for at analysere, hvad den lyttende gør, når lytning opleves - her af klienter i alternative behandlingsklinikker. Hvad er det for en praksis, der overbeviser klienten om at være forstået af behandleren? Alle sanser synes at være i spil, og lytning er mere end konversation. Brugere af alternativ behandling værdsætter behandleres inddragelse af andet end det, der bliver sagt, for eksempel opbygningen af relationen mellem behandler og klient og ikke kun vægtningen af fysiologiske data. Artiklen anlægger et dobbeltperspektiv ved at tage udgangspunkt i såvel brugeres erfaringer som forskerens egne erfaringer og fremgangsmåde. Således demonstreres værdien af at praktisere lytning i en behandlings-, men også i en fænomenologisk undersøgelsessammenhæng.

Søgeord: alternativ behandling, brugerperspektiv, praksis, kropsfænomenologi, Merleau-Ponty

\section{Anette Stenslund: Kom nærmere. Lugten i galleriet}

Baseret på erfaringer hentet fra den allerførste museumsudstilling nogensinde dedikeret udelukkende til duft, problematiserer jeg i artiklen det abstrakte objektiverende niveau, dufte ofte håndteres på. Jeg viser, at objektiverende tilgange til duft fordrer en eksistentiel distance, og i et forsøg på at komme nærmere lugterfaringers ontologiske fundament introducerer jeg en alternativ tilgang udviklet 
med inspiration hentet hos Martin Heidegger. På baggrund af min ambition om at udvikle en fænomenologisk sensitiv tilgang til håndtering af det ontologiske spørgsmål om, hvad lugt er, supplerer jeg allerede eksisterende lugtundersøgelser, og jeg foretager væsentlige justeringer af begrebet tilstedeværelse, som findes i værker af Hans Ulrich Gumbrecht. Ved at fremhæve den menneskelige eksistens som en del af olfaktoriske fænomener afdækker denne fænomenologiske undersøgelse lugtens grundlæggende ontologi. Lugt er altid „noget til nogen“. Lugtoplevelser er således universelt partikulære og kan alene objektiveres regionalt.

Søgeord: Olfaktorisk æstetik, tilstedeværelse, nærværelse, Martin Heidegger

\section{Susanne Ravn: Om kropsbevidsthed og bevægelsesfornemmelser. En fænome- nologisk beskrivelse af danseres bevægelsesekspertise}

I denne artikel kombineres fænomenologi og etnografiske metoder med det formål at beskrive, hvorledes dansere bruger deres kropsbevidsthed og arbejder med deres bevægelsesfornemmelse. Artiklens formål forfølges i to empiriske undersøgelser. Den første undersøgelse har afsæt i professionelle danseres daglige praksis relateret til henholdsvis ballet og moderne danseteknikker. Dansernes beskrivelser viser, at kroppens fysikalitet kan være nærværende for bevidstheden som en fornemmelse, uden at der er tale om et refleksivt foretagende, og uden at kroppen fremtræder som objekt. Denne fornemmelse udgør en vigtig ekstra, eller tredje, dimension af dansernes kropslige selvbevidsthed og deres bevægelsesekspertise. Den anden undersøgelse omhandler argentinsk tango og sportsdans. I begge former for pardans har partnerens bevægelser helt grundlæggende betydning for dansernes bevægelsesfornemmelse. Fænomenologisk set er der tale om en kropslig ekstension: Den bevægelsesfælleshed, der etableres i interaktionen, er en betingelse og et udgangspunkt for sansningen af bevægelserne. Dansernes beskrivelser peger dog også på, at interaktionen kan være i fokus i forskellig grad. De to fænomenologisk relaterede analyser udfordrer dermed ideen om at kroppen skulle være fraværende for bevidstheden, når dansefærdighederne beherskes. I stedet er en tredje dimension af dansernes kropslige selvbevidsthed central for danserens præstation, og fornemmelser af bevægelsesfællesheder bearbejdes strategisk.

Søgeord: tværvidenskabelig metodologi, danseforskning, professionelle dansere, argentinsk tango, sportsdans 


\section{Martin Lindhardt: Når religionen sætter sig i kroppen. Om fænomenologiske drejninger i antropologisk ritualteori}

Denne artikel belyser fænomenologiske drejninger i antropologisk ritualteori. Jeg trækker både på andre forskeres arbejde og på min egen forskning i pinsekristendom i Tanzania og Chile, idet jeg argumenterer for, at et fænomenologisk fokus på forskellige erfaringsmåder og ikke mindst på den inkarnerede væren-i-verden kan nuancere klassiske definitioner af religion, som relaterer til propositionel tro (for eksempel tro på, at Gud eksisterer), ideer og symbolsystemer. Artiklen ser blandt andet på, hvordan den kropslige deltagelse i rituel praksis kan resultere $\mathrm{i}$ produktionen af rituelle agenter, der i tilgift til at have en særlig tro og særlige verdenssyn besidder en praktisk rituel viden i form af færdigheder, dispositioner og en intuitiv sensibilitet $\mathrm{i}$ forhold til det hellige. Endvidere argumenterer jeg for, at kropslig rituel praksis i mange tilfælde bør ses som konstituerende for religiøst liv og ikke bare som en materialisering af forudeksisterende religiøs tro og religiøse ideer.

Søgeord: ritual, fænomenologi, krop, spontanitet, færdigheder, betydning, tro, pinsekristendom, Tanzania, Chile 